\title{
Diagnosis of Sustainability in the Food Engineering Creation Program of the Polytechnic University of the State of Carchi (UPEC) in the Substantive Function "Teaching"
}

\author{
Liliana Chamorro-Hernández¹, Judith García², Darwin Casaliglla3 ${ }^{3}$, Martin Campos-Vallejo², \\ Luis Núñez-Naranjo ${ }^{4,5}$, Jorge Mina ${ }^{1}$
}

${ }^{1}$ Food Engineering Career, Carchi State Polytechnic University, Tulcán, Ecuador

${ }^{2}$ Agricultural Career, Carchi State Polytechnic University, Tulcán, Ecuador

${ }^{3}$ Computer Career, Carchi State Polytechnic University, Tulcán, Ecuador

${ }^{4}$ Department of Pathology, College of Veterinary Medicine, University of Sao Paulo, Sao Paulo, Brazil

${ }^{5}$ Facultad de Ciencias de la Salud, Carrera de Medicina Veterinaria, Universidad de Las Américas, Quito, Ecuador

Email: rolando.campos@upec.edu.ec

How to cite this paper: Chamorro-Hernández, L., García, J., Casaliglla, D., Campos-Vallejo, M., Núñez-Naranjo, L., \& Mina, J. (2018). Diagnosis of Sustainability in the Food Engineering Creation Program of the Polytechnic University of the State of Carchi (UPEC) in the Substantive Function "Teaching". Creative Education, 9, 1957-1968.

https://doi.org/10.4236/ce.2018.913143

Received: September 14, 2018

Accepted: October 19, 2018

Published: October 22, 2018

Copyright $\odot 2018$ by authors and Scientific Research Publishing Inc. This work is licensed under the Creative Commons Attribution International License (CC BY 4.0).

http://creativecommons.org/licenses/by/4.0/

cc) (i) Open Access

\begin{abstract}
As the world population grows, technologies are developed to improve food industrialization processes that are characterized by using large amounts of resources that modify social, economic, political and environmental systems that are the main components of sustainability. The incorporation of sustainability in Higher Education Institutions in Latin America is a relatively new process; it initiates with the implementation of study programs that promote a society responsible with the environment. The objective of this investigation was to diagnose the Creation Program of Food Engineering of the Polytechnic University of the State of Carchi (UPEC) in the substantive function "Teaching" to know the current situation in relation to sustainability. The main contribution of this research was designing a new methodology for evaluation of sustainability, taking the Sustainable Development Objectives from UN 2015 as a reference for calculating the percentage of sustainability contained in the curriculum. There were no references to similar diagnosis made in other universities in the world that could serve as reference for the present investigation. The percentage of hours with sustainability content was calculated as $24.15 \%$ considering teaching hours that showed sustainability contents, this was the Overall Sustainability Percentage. Human related courses presented greater percentage of sustainability. The most common Sustainable Development Objective was "Health and wellbeing". The presence of the 17
\end{abstract}


UN Sustainable Development Objectives is evident but below 50\%, presenting a possibility of improvement. There is a fertile ground for the incorporation of the sustainability approach in the career of Food Engineering in the UPEC, which with only four years of creation; it is a suitable institutional time to consolidate a commitment to food production, conservation and industrialization in a sustainable way, with the urgency demanded by today situation.

\section{Keywords}

Higher Education Institutions, Study Programs, UN Sustainable Development Objectives

\section{Introduction}

Food production and conservation have developed as population has grown. Nowadays the standards of food quality and safety are more demanding at the governmental level, in food production companies and in each home. The advances in food production have provoked a social, economic, political and environmental crisis due to ignorance of causes and effects that directly and indirectly cause production processes and their industrialization. $18 \%$ of humanity consumes $80 \%$ of vital resources; this means that if a region needs more hectares per capita (resources) to maintain its high consumption, the other region is necessarily forced to occupy less. Hence, profound inequality in the distribution and uses of goods and the character of inequality in global consumption processes are understood (Angiolini, 2015).

Industrialized or conventional food production systems of animal origin have focused on production at low cost (Kulo \& Vramo, 2007) without considering other factors closely related to the production chain (Challenger, 1998), causing negative effects on social, economic, environmental, in human diet and in animal welfare, among others (Fraser, 2001), which has generated in recent years a greater interest on the part of consumers towards these effects (Reisch, 2004).

Due to these, various alternative food production systems have included, within their policies, characteristics of sustainable production with emphasis on environment protection and food safety, in addition to animal welfare and fair trade (Enkerlin, Cano, Garza, \& Vogel, 1998; Sayer \& Cambell, 2004; Gamborg \& Sandoe, 2005; Wiberg, Algers, Franken, Lindercrona, \& Moen, 2007). These changes had been generated mainly by pressure and interest of consumers and general public (Kjarnes, 2007).

Although there are endless attributes that characterize a sustainable food production of animal origin, those that are considered directly related to the consumer, and have a greater demand in the world food industry are: 1) environmental protection; 2) fair trade; 3) animal welfare; 4) food safety (Gamborg \& Sandoe, 2005; Santurtún et al., 2012). As Broom said in 2004: "no production 
system will be sustainable if the majority of people find it unacceptable".

There are different natural resources that benefit humanity, such as obtaining food from agriculture, livestock and fishery. Other benefits are the compounds used in synthesized medicine by living organisms, fuels for industry creation and intangible services provided by some living beings, such as oxygenation, carbon capture, climate regulation, pollination, and essential elements for human life. The conservation and sustainable use of all these resources is fundamental for permanence of living world (Instituto Nacional de Tecnología Agropecuaria, 2013).

World Commission on Environment and Development of United Nations (UN) in 1987, created the definition of sustainable development, which aims at homogeneity and coherence between economic growth, natural resources and society, starting from a harmonious coexistence between humanity and environment, managing to satisfy the present needs for natural resources, and in the same way protecting them by creating promotion patterns that ensure a well-balanced use of resources and their reproduction, so that new generations can also take advantage of resources.

The global crisis that economy has experienced since 2008 with devastating effects for hundreds of millions of people, shows that current economic structure is moving in the opposite direction to sustainability. Satisfying basic human needs has not been a priority of the productive structure; an example of this is the production of fuels of vegetable origin at the expense of food production, which has had serious consequences in terms of food security (Grave, La, Alimentaria, \& Regiones, 2008).

Due to its social and economic implications, food industry occupies a privileged place in this controversy, even though from the economic perspective it is not considered as a determining activity of global competitiveness, it deserves special treatment by many nations because it is vital for survival of population and is the foundation of economy of many countries, especially the poorest. In other words, it stands out for its strategic nature. Thus, a large part of disputes that are most frequently settled in the World Trade Organization (WTO) are related to agriculture and food processing.

Technologically, food industry is recognized as mature with little capacity to generate important technological changes (Wilkinson, 2002; Castellacci, 2004); however, in recent years there has been a renewal of its innovative possibilities thanks to the development of sophisticated process control systems, which meet global safety and quality standards.

At the end of the Second World War began the strengthening of living conditions of population, this meant assuming the notion of development, initially linked to solve hunger (social component) and then incorporate economic and environmental, all of them are components of sustainability. It was also created under the lead of the United States of America, in order to point out a horizon of progress to countries that were classified as underdeveloped-Latin America, 
Africa, Asia, in contrast with countries identified as developed, among them; United States, England, France, Germany, Holland, Denmark, Norway, Sweden, among others (Ramirez, 2015). This process proposed 17 Sustainable Development Goals (SDG) in "Agenda 2030 for sustainable development". The Sustainable Development Goals are intended to create a set of global objectives related to environmental, political and economic challenges facing our world.

SDGs are a commitment to solve the most urgent problems facing the world today. The 17 Objectives are interrelated, which means that one's success affects others. Responding to the threat of climate change affects the way we manage our fragile natural resources. Achieving gender equality or improving health helps eradicate poverty; and promoting peace and inclusive societies will reduce inequalities and contribute to the prosperity of economies. In short, it is an unparalleled opportunity for the benefit of future generations (UN, 2015).

Universities provide the basis for democracy and citizen ethics that seeks to establish the essential agreements for a peaceful and sustainable society (Bermudez, 2016). The incorporation of sustainability in Higher Education Institutions HES in Latin America is a relatively new process, it is carried out through its incorporation into study programs, research projects and links with society due to its direct relationship with the creation of a responsible society with environment (Gonzalez, Meira, \& Martínez, 2015).

The Education Commission created by the International Union for Conservation of Nature in 1949, was the first institution that promoted the incorporation of "education for nature conservation" in HES, with environmental education being the main axis of sustainability. According to Sáenz \& Benayas (2015); in Colombia from 1950 on, the universities began to offer technical and professional training programs for use and conservation of natural resources.

The educational role of universities in society is indisputable; they train generations of young people who in the future are key decision makers, society puts in public and private commands those who have had the opportunity to be trained in university classrooms, thus university cannot ignore this relevant fact; it is their graduates who have to make the important and relevant decisions.

Universities have ethical mandate to address education for sustainable development from three traditional areas that characterize it: teaching, research and linking to society.

Teaching is aimed at training professionals capable of contributing to sustainable development, including in curricular meshes and in different courses the environmental issue from the perspective of each career, and a general formation of values that ensures commitment of future policy holders with decisions and actions that do not threaten sustainability and allow the establishment of a distinctive seal to students of a specific university.

UPEC was created in 2006 and it was in 2014 that Food Engineering Career began. The challenge is to train professionals with a new profile that is accompanied by a change in integral formation of teachers, by the way of learning and 
practicing teaching, by management carried out with sustainability, teamwork to protect natural resources, human welfare of all living beings, and in general, searching for a greater good.

For this reason, the objective of this investigation was to make a diagnosis of UPEC Food Engineering Creation program in the substantive function "Teaching" to know the current situation in relation to sustainability.

\section{Materials and Methods}

The present study was applied to UPEC Food Engineering Creation Program, and there were three groups of courses: Humanities, Basic Sciences, and Professional Unit.

The methodology applied was content analysis technique. According to Elo, Kääriäinen, Kanste, Pölkki, Utriainen, \& Kyngäs in 2014, Qualitative content analysis can be used in either an inductive or a deductive way. Both processes involve three main phases: preparation, organization, and reporting of results. The preparation phase consists of collecting suitable data for content analysis, making sense of the data, and selecting the unit of analysis. In the inductive approach, the organization phase includes open coding, creating categories, and abstraction. In deductive content analysis, the organization phase involves categorization matrix development, whereby all the data are reviewed for content and coded for correspondence to or exemplification of the identified categories. The categorization matrix can be regarded as valid if the categories adequately represent the concepts, and from the viewpoint of validity, the categorization matrix accurately captures what was intended. In the reporting phase, results are described by the content of the categories describing the phenomenon using a selected approach.

The presence of sustainability in the career was determined in two ways; calculating percentage of courses in the curriculum with some sustainability content and percentage of teaching hours with sustainability content.

The percentage of sustainability was calculated taking as reference the 17 Sustainable Development Goals (SDG) created in 2012, shown in Table 1, and compared with the contents of each of the courses in the curriculum of the Career Creation Program. The UPEC Food Engineering until 2017 had taught only the first six levels of ten, the courses were evaluated considering the syllables of the six levels taught and the rest was evaluated with the minimum contents of each course established in the Creation Program.

The number of teaching hours was determined considering that a credit is equivalent to 16 hours therefore there were courses with $32,48,64,80$ and 96 teaching hours. For this, in the analysis of the syllables and/or minimum contents, the number of contents that explicitly established the presence of sustainability was found and was divided by the number of contents of each course, to determine a percentage. This percentage was multiplied by the number of hours of the course and this was the number of hours that the teacher dedicated to 
Table 1. Sustainable Development Goals (SDG).

\begin{tabular}{|c|c|c|}
\hline $\begin{array}{c}\text { SDG } \\
\text { number }\end{array}$ & SDG name & Description \\
\hline 1 & End of Poverty & Ending poverty in all its forms throughout the world. \\
\hline 2 & Zero Hunger & $\begin{array}{l}\text { Ending hunger, achieving food security } \\
\text { and improving nutrition and promoting } \\
\text { sustainable agriculture. }\end{array}$ \\
\hline 3 & Health and Wellbeing & $\begin{array}{l}\text { Ensure a healthy life and promote } \\
\text { well-being for all at all ages. }\end{array}$ \\
\hline 4 & Quality Education & $\begin{array}{l}\text { Ensure an inclusive, equitable and quality education } \\
\text { and promote lifelong learning opportunities for all. }\end{array}$ \\
\hline 5 & Gender Equality & $\begin{array}{l}\text { Achieve gender equality and empower } \\
\text { all women and girls. }\end{array}$ \\
\hline 6 & $\begin{array}{l}\text { Clean Water and } \\
\text { Sanitation }\end{array}$ & $\begin{array}{c}\text { Guarantee the availability of water and its sustainable } \\
\text { management and sanitation for all. }\end{array}$ \\
\hline 7 & $\begin{array}{c}\text { Free and Non-Polluting } \\
\text { Energy }\end{array}$ & $\begin{array}{l}\text { Guarantee access to affordable, safe, } \\
\text { sustainable and modern energy for all. }\end{array}$ \\
\hline 8 & $\begin{array}{l}\text { Decent Work and } \\
\text { Economic Growth }\end{array}$ & $\begin{array}{l}\text { Promote sustained, inclusive and sustainable } \\
\text { economic growth, full and productive } \\
\text { employment and decent work for all. }\end{array}$ \\
\hline 9 & $\begin{array}{l}\text { Industry, Innovation and } \\
\text { Infrastructure }\end{array}$ & $\begin{array}{l}\text { Build resilient infrastructures, promote inclusive } \\
\text { and sustainable industrialization and } \\
\text { encourage innovation. }\end{array}$ \\
\hline 10 & Reduction of Inequalities & Reduce inequality in and between countries. \\
\hline 11 & $\begin{array}{l}\text { Sustainable Cities and } \\
\text { Communities }\end{array}$ & $\begin{array}{l}\text { To make cities and human settlements } \\
\text { inclusive, safe, resilient and sustainable. }\end{array}$ \\
\hline 12 & $\begin{array}{l}\text { Responsible Production } \\
\text { and Consumption }\end{array}$ & $\begin{array}{l}\text { Ensure sustainable consumption } \\
\text { and production patterns. }\end{array}$ \\
\hline 13 & Action for Climate & $\begin{array}{l}\text { Adopt urgent measures to combat } \\
\text { climate change and its effects. }\end{array}$ \\
\hline 14 & Underwater Life & $\begin{array}{c}\text { Conserve and sustainably use oceans, seas and marine } \\
\text { resources for sustainable development. }\end{array}$ \\
\hline 15 & $\begin{array}{l}\text { Life of Terrestrial } \\
\text { Ecosystems }\end{array}$ & $\begin{array}{l}\text { Sustainably manage forests, fight against } \\
\text { desertification, stop and reverse land } \\
\text { degradation and stop the loss of biodiversity. }\end{array}$ \\
\hline 16 & $\begin{array}{l}\text { Peace, Justice and Solid } \\
\text { Institutions }\end{array}$ & Promote societies, just, peaceful and inclusive. \\
\hline 17 & $\begin{array}{l}\text { Partnerships to achieve } \\
\text { Objectives }\end{array}$ & $\begin{array}{l}\text { Revitalize the Global Partnership } \\
\text { for Sustainable Development. }\end{array}$ \\
\hline
\end{tabular}

Source: UN (2015)

sustainability associated contents. Subsequently, the overall sustainability percentage of the career was calculated. The mathematical model created for this evaluation was: 


\section{$\%$ SUSTAINABILITY \\ $=\frac{\text { TOTAL HOURS DEDICATED TO SUSTAINABILITY CONTENTS }}{} \times 100$ TOTAL TEACHING HOURS}

All this information was emptied into two matrices called Mesocurricular and Microcurricular Dimension Levels. The Mesocurricular Dimension Matrix contained headings that register: Faculty, Career, Criterion, Present, Absent, Courses and Teaching Hours. In the column called Criterion was placed: $\mathrm{Hu}-$ manities, Basic Sciences and Professional Unit that correspond to the Units of Curricular Organization (UCO), in Present the number of hours that each course dedicated to impart contents that addressed sustainability, in Absent the number of total hours minus the number of hours dedicated to sustainability, in Courses all the courses present in the curricular mesh, and in Teaching hours the number of hours per course taught by the teacher.

The Microcurricular Dimension Matrix contained headings such as Faculty, Career, Course and Observation. In Observation, the paragraph of the document (Syllabus or Minimum Contents) that mentioned a sustainability criterion was transcribed and which SDG was more closely related to it.

\section{Results}

As shown in Table 2, the number of courses that formed the curricular mesh at career creation were 58 of which 27 presented sustainability contents, which represented $46.5 \%$ of the courses thought in the career have sustainability contents in an explicit way. Of the nine Humanities courses eight presented sustainability contents, which means $88.8 \%$. This high percentage is due to the fact that this group was directly related to society topics such as Life Project, Socioeconomic and Cultural Reality, Human Talent, among others.

The Basic Sciences formed a group of 24 courses of which nine presented sustainability corresponding to $37.5 \%$. This group had courses that are based on calculation, such as Physics, Chemistry, Mathematics among others, that is why there was little evidence of sustainability in them.

The Professional Unit consisted of 25 courses of which 10 have sustainability that represents $40 \%$. This group sees an opportunity for improvement due to the importance of presence of sustainability in preparation and marketing of safe

Table 2. Percentage of courses with sustainability contents in curricular mesh in UPEC food engineering creation program.

\begin{tabular}{cccc}
\hline Criterion & $\begin{array}{c}\text { Total } \\
\mathrm{N}^{\circ} \text { courses }\end{array}$ & $\begin{array}{c}\mathrm{N}^{\circ} \text { courses with } \\
\text { sustainability }\end{array}$ & \% sustainability \\
\hline Humanities & 9 & 8 & 88.8 \\
Basic Sciences & 24 & 9 & 37.5 \\
Professional Unit & 25 & 10 & 40.0 \\
Total & 58 & 27 & 46.5 \\
\hline
\end{tabular}

Note: All percentages were calculated within each row. 
food and health and well-being of humans.

Table 3 shows teaching hours that are contemplated in the curriculum, they were 3168 hours of which 765.36 hours were related to the SDG which corresponds to $24.15 \%$, this was the Overall Sustainability Percentage.

Humanistic courses presented more hours of sustainability (46.25\%), of 384 teaching hours 177.63 were related to SDGs, followed by Professional Unit with $33.85 \%$ and finally Basic Sciences with 5.4\%.

It is interesting to analyze that sustainability percentages based on the number of courses were higher than those based on the number of hours; this is due to the fact that in some cases there were courses that have sustainability content but dedicate few hours to it.

Table 4 associates the SDG with courses that were in the curriculum. It was observed that humanistic courses had more sustainability courses and hours, and were related to 13 of the 17 SDGs; being SDGs 3 and 4 the most frequent. The SDGs that were not present were 1, 2, 6 and 14, these objectives include technical goals related to end of hunger, poverty, clean water and underwater life, which were not related to Humanistic.

Basic Sciences are related to nine SDGs, with SDGs 3, 8 and 17 as most frequent, this indicates that greater attention was given to training in Health and Wellbeing, Decent Work and Economic Growth and Strategic Alliances for they are fundamental for Food engineering.

In Professional Unit SDGs 2, 3, 9 and 12 were the most frequent, due to the importance of Reducing Hunger, Health and Wellbeing for populations, Industry, Innovation and Infrastructure and Responsible Production and Consumption; therefore, these topics are of primary interest in this program.

In general, the most frequent SDGs were 3, 8, 9, 12 and 17. SDGs that were

Table 3. Percentage of teaching hours with sustainability contents in curricular mesh in UPEC food engineering creation program.

\begin{tabular}{cccc}
\hline Criterion & $\begin{array}{c}\text { Total } \\
\mathrm{N}^{\circ} \text { hours }\end{array}$ & $\begin{array}{c}\mathrm{N}^{\circ} \text { hours with } \\
\text { sustainability }\end{array}$ & \% sustainability \\
\hline Humanities & 384 & 177.63 & 46.25 \\
Basic Sciences & 1248 & 67.71 & 5.4 \\
Professional Unit & 1536 & 520.02 & 33.85 \\
Total & 3168 & 765.36 & 24.15 \\
\hline
\end{tabular}

Note: All percentages were calculated within each row.

Table 4. Association of SDG with evaluated criterion in UPEC food engineering creation program.

\begin{tabular}{cc}
\hline Criterion & SDGs \\
\hline Humanities & $3,4,5,7,8,9,10,11,12,13,15,16,17$. \\
Basic Sciences & $1,2,3,4,7,8,9,12,17$. \\
Professional Unit & $1,2,3,8,9,11,12,13,16,17$
\end{tabular}


not present: SDG 6 "Guarantee the availability of water and its sustainable management and sanitation for all" and SDG 14 related to underwater life; because they are not competences of Food Engineering.

\section{Discussion}

To promote production, processing and supply of food in a sustainable way, training of professionals and technicians with a new profile is required. Teaching models based on technical rationality, with fragmentary views of reality, must be replaced by overcoming developments that derive from systems approaches that consider an agro ecological perspective. This new vision must be accompanied by a change in the integral formation of teachers and changes in teaching (Sarandón, 2002).

The present investigation shows a diagnosis of UPEC Food Engineering Creation Program in the substantive function "Teaching" in order to know the current situation in relation to sustainability. There were no references to similar diagnoses made in other universities in the world that could serve as reference for the present investigation; that is why the percentage of sustainability found is considered low considering that it is below $50 \%$.

The results showed the presence of sustainability both in syllabus and minimum contents in the curriculum mesh of Food Engineering Creation Program, even though the career was not created with this as a transversal axis. Unlike Sáenz and Benayas said in 2015, that since 1999 in Colombia they have offered 190 programs related to environment and development and increased this number to 465 in 2006 and that in Mexico the growth of offers of academic programs in the area of Environmental studies was "explosive", as it went from 290 programs in 1993 to 1399 in 2001.

More and more universities feel committed to train professionals that contribute to transform realities in lifestyles, and participation and consumption patterns of citizens promote production processes, economies, industries with low impact technologies and less pressure on the environment, as well as working on the environmental training of decision makers and entities of governments with competences in all aspects of the transformation of ecosystems. In some research reported by Zamudio in 2015, on environmental education in higher education, they stated that the curriculum is an important axis for incorporation of sustainability in universities.

On the other hand, Moran cited by Molano and Herrera in 2014, about environmental education, stated that this should be done in spaces other than formal curriculum or academic curriculum, considering that the rigidity of planning of dominant academic structure in universities does not allow inclusion of the topic in an adequate way. On the contrary; Escudero, cited by Molano and Herrera, stated that environmental training must be carried out in the curriculum, assuming the term as the organization of courses in certain times and spaces in universities. 
It is interesting to note that in the Food Engineering of the UPEC on tenth level, they teach a course called Environmental Impact, that has a high degree of sustainability in its contents, this coincides with a course taught at the University of San Juan in Argentina (Angiolini, 2015) and both are explicitly and directly related to sustainability.

This research established bases for sustainability evaluation of future and ongoing university programs in order to achieve curricula that contain high percentages of sustainability and also help those programs that do not have an adequate level in order to improve them.

No restrictions were imposed in the analysis of documents in the UPEC, therefore the investigation group could access to all documents and the authorities were willing to collaborate providing funds to do so. All nine careers in UPEC are going through this evaluation process in order to have complete information of the changes that are necessary to make to be a Sustainable University. Future investigation will have the results of the substantive functions "Investigation" and "Linking to Society" in Food Engineering Career and the remaining careers taught in UPEC.

With interpretation and analysis of similar information obtained in all nine careers that are taught at the moment at State Polytechnic University of Carchi UPEC; it was intended to make a proposal and suggest the design of a sustainable educational model that allows the authorities to have a starting point to draw policies in a framework of sustainable education.

\section{Conclusions}

The diagnosis of UPEC Food Engineering Creation program leads to the following assertions:

- The methodology created to compare contents of curricular courses with the 17 SDGs of the UN is applicable to determine the percentage of sustainability in curricula in Higher Education Programs.

- Sustainable development was not the central axis of the curriculum in UPEC Food Engineering Creation program however it existed in many of its contents.

- There were courses in UPEC Food Engineering Creation program that presented sustainability in their contents, but the number of hours dedicated to impart them was very few.

- The percentage of courses and the percentage of teaching hours with sustainability contents were less than $50 \%$, presenting a possibility of improvement.

- Of nine Humanistic courses, eight presented sustainability contents; Basic Sciences form a group of 24 courses, of which nine present sustainability and in Professional Unit of 25 curricular courses 10 have sustainability contents.

- The teaching hours contemplated in the curriculum were 3168 , of which 765.36 were related to the SDG, which corresponds to $24.15 \%$, this was the 
Overall Sustainability Percentage.

- SDGs 3, 8, 9, 12 and 17 were present in all the Creation Program Units (Humanities, Basic Sciences and Professional Unit. The most common Sustainable Development Objective was "Health and wellbeing".

- SDG 6 "Guarantee the availability of water and its sustainable management and sanitation for all" and SDG 14 related to underwater life; were not present in any of the Creation Program Units because they are not competences of Food Engineers.

- There is a fertile ground for incorporation of sustainability approach in UPEC Food Engineering, which with only four years of creation, is a suitable institutional moment to consolidate commitment with food production, conservation and industrialization in a sustainable way with the urgency demanded by today situation.

\section{Recommendations}

It is recommended to make a proposal of an Educational Model for UPEC focused on sustainability.

\section{Acknowledgements}

To the Carchi Polytechnic University for all of the facilities provided in the course of this study.

\section{Conflicts of Interest}

The authors declare no conflicts of interest regarding the publication of this paper.

\section{References}

Angiolini, S. (2015). La sustentabilidad en el currículum del arquitecto en la Universidad Pública Argentina. Estoa, 4, 69-76. https://doi.org/10.18537/est.v004.n007.08

Bermúdez, O. M. (2016). Educación Ambiental, Valores y Prácticas Sustentables. Una Guía para Educadores del siglo XXI. Bogotá: Colombia. IDEAS 26.

Broom, D. M. (2004). Future Food Animal Production Efficiency and Acceptability. In Z. H. Shamsuddin (Ed.), Agriculture Congress: Innovation towards Modernized Agriculture (pp. 17-21). Serdang: University Putra Malaysia.

Castellacci, F. (2004). How Does Innovation Differ Across Sectors in Europe? Evidence from the CIS-SIEPI Database. Centre for Technology, Innovation and Culture. Workingpaper, núm. 4, Oslo: University of Oslo.

Challenger, A. (1998). Utilización y conservación de los ecosistemas terrestres de México. Pasado, Presente y Futuro. México DF: CONABIO, Instituto de Biología, UNAM y Sierra Madre AC.

Elo, S., Kääriäinen, M., Kanste, O., Pölkki, T., Utriainen, K., \& Kyngäs, H. (2014). Qualitative Content Analysis: A Focus on Trustworthiness. SAGE Open, 4, Issue 1. https://doi.org/10.1177/2158244014522633

Enkerlin, E. C., Cano, G., Garza, R. A., \& Vogel, E. (1997). Ciencia Ambiental y Desarrollo Sostenible. México D.F: International Thomson Editores. 
Fraser, D. (2001). The "New Perception" of Animal Agriculture: Legless Cows, Featherless Chickens, and a Need for Genuine Analysis. Journal of Animal Science, 79, 634-641. https://doi.org/10.2527/2001.793634x

Gamborg, C., \& Sandoe, P. (2005). Sustainability in Farm Animal Breeding: A Review. Livestock Production Science, 92, 221-233. https://doi.org/10.1016/j.livprodsci.2004.08.010

González, E. J., Meira-Cartea, P. A., \& Martínez-Fernández, C. N. (2015). Sustentabilidad y Universidad: Retos, ritos y posibles rutas. Revista de la Educación Superior, 44, 69-93.

Instituto Nacional de Tecnología Agropecuaria (2013). La importancia de la preservación en la biodiversidad. https://inta.gob.ar/noticias/la-importancia-de-la-preservacion-en-la-biodiversidad

Kjarnes, U. (2007). Ethics and Action: A Relational Perspective on Food Trends and Consumer Concerns. In Sustainable Food Production and Ethics: Preprints of the 7th Congress of the European Society for Agricultural and Food Ethics (pp. 43-48). Vienna: Wageningen Academic Publishers.

Kulo, M., \& Vramo, L. M. (2007). Sheep Welfare in the Welfare State: Ethical Aspects of the Conventionalization of Norwegian Organic Production. In Sustainable food Production and Ethics (pp. 273-278). Vienna: Wageningen Academic Publishers.

Molano, A., \& Herrera, J. (2014). La Formación Ambiental en la educación Superior: Una revisión necesaria. Luna Azul, 39, 186-206.

Grave, C. U., La, A. P., Alimentaria, S., \& Regiones, M. (2016). El estado mundial de la agricultura y la alimentación.

Ramirez, A. I. (2015). Educación, Pedagogía y Desarrollo Rural. Ideas para construir la paz. Bogotá: Colombia Eco-ediciones.

Reisch, L. (2004). Principles and Visions of a New Consumer Policy. Journal of Consumer Policy, 27, 1-42. https://doi.org/10.1023/B:COPO.0000014103.38175.df

Sáenz, O., \& Benayas, J. (2015). Ambiente y Sustentabilidad en las instituciones de Educación Superior En América Latina y El Caribe. Revista Iberoamericana Universitaria en Ambiente, Sociedad y Sustentabilidad, 1, 192-224.

Santurtún, E., Tapia, G., Pérez, C., González, C., \& Galindo, F. (2012). Actitudes y percepciones de consumidores en la Ciudad de México, hacia atributos de la producción sustentable de alimentos de origen animal. Veterinaria México, 43, 87-101.

Sarandón, S. (2002). Incorporando el enfoque agroecológico en las Instituciones de Educación Agrícola Superior: La formación de profesionales para una agricultura sustentable. Agroecologia e Desenvolvimento Rural Sustentáve Porto Alegre, 3, 40-48.

Sayer, J. A., \& Campbell, B. M. (2004). The Science of Sustainable Development: Local Livelihoods and the Global Environment. Cambridge: Cambridge University Press.

UN, G. A. (2015). Transforming Our World: The 2030 Agenda for Sustainable Development. A/RES/70/1.

Wiberg, S., Algers, A., Algers, B., Franzen, U., Lindencrona, M., \& Moen, O. (2007). Logistics at Transport to Slaughter: Food and Environment-Optimized Animal Transport.

Wilkinson, J. (2002). The Final Foods Industry and the Changing Face of the Global Agrifood System. Sociologia Ruralis, 42, 329-346.

Zamudio, C. (2015). Educación ambiental en la educación superior. Consideraciones teóricas y metodológicas. Bogotá: Universidad Distrital Francisco José de Caldas. 